\title{
Oral mucosa alterations in a socioeconomically deprived region: prevalence and associated factors
}

\author{
Raquel Gonçalves \\ Vieira-Andrade ${ }^{(a)}$ \\ Flávia de Faria Zuquim \\ Guimarães $^{(b)}$ \\ Charlles da Silva Vieira ${ }^{(b)}$ \\ Sarah Teixeira Carvalho Freire(b) \\ Maria Letícia Ramos-Jorge(a) \\ Anacélia Mendes Fernandes ${ }^{(b)}$
}

(a) Departament of Pediatric Dentistry, School of Dentistry, Federal University of Vales of Jequitinhonha and Mucuri, Diamantina, MG, Brazil.

(b) Departament of Stomatology, School of Dentistry, Federal University of Vales of Jequitinhonha and Mucuri, Diamantina, MG, Brazil.

\begin{abstract}
This study aimed to evaluate the prevalence and factors associated with oral mucosa alterations in patients from Vale do Jequitinhonha, Brazil. The sample consisted of 511 patients of both genders. Questionnaires were used to obtain information about patient gender, age, race, systemic disease state, medication use, cigarette use and alcohol consumption. Physical examinations were then performed to identify lesions of the oral mucosa. Descriptive analyses, Chi-squared tests and logistic regressions were then used to analyze the results $(\mathrm{p}<0.05,95 \%$ CI). In this population, $84.9 \%$ (434/511) of patients were found to have alterations in their oral mucosa. The most common alterations were melanotic maculae $(36.0 \%)$, linea alba $(33.9 \%)$, traumatic ulcers $(21.5 \%)$, Fordyce's granules $(20.4 \%)$, coated tongue $(12.5 \%)$ and fissured tongue $(10.0 \%)$. Melanotic maculae were more frequently observed in black patients, with an odds ration (OR) of 7.51. Being female was a statistically significant predictive factor for having a visible linea alba (OR: 1.90) and a fissured tongue (OR: 2.11). No statistically significant association was found between the presence of oral lesions and systemic disease, medication use, alcohol use and smoking. The high observed prevalence of melanotic maculae and Fordyce's granules suggests that these alterations could be considered typical characteristics of the population of the Vale do Jequitinhonha. Coated tongue may be related to the socioeconomic deprivation in the region. Furthermore, the high prevalence of traumatic ulcers may be associated with the traumatic agents that caused patients to seek dental care.
\end{abstract}

Descriptors: Mouth Mucosa; Mouth Diseases; Prevalence.

\begin{abstract}
Declaration of Interests: The authors certify that they have no commercial or associative interest that represents a conflict of interest in connection with the manuscript.
\end{abstract}

Corresponding Author:

Raquel Gonçalves Vieira-Andrade

E-mail: raquelvieira.andrade@gmail.com

Received for publication on May 02, 2011 Accepted for publication on Aug 26, 2011

\section{Introduction}

The diagnosis of oral mucosa alterations depends on the ability of dentists to distinguish between pathological changes and normal variation within the oral structures. ${ }^{1}$ A knowledge of normal alterations and lesions and their association with systemic changes, deleterious habits and medication use is therefore essential for the diagnosis, treatment and establishment of prevention policies. ${ }^{2}$

Studies in various parts of the world have reported the prevalence of oral mucosa alterations, as well as their association with systemic changes and with deleterious habits such as smoking and alcohol consumption. The prevalence rates of such alterations usually vary with gender, age, 
race and socioeconomic status. ${ }^{3-14}$

The Vale do Jequitinhonha is a region largely known for its low social indicators and is currently one of the areas of greatest inequality and social exclusion in Brazil. ${ }^{15}$ The microregion of Diamantina is located in this region and is known as the gateway to the Vale do Jequitinhonha.

Despite the socioeconomic deprivation faced by many inhabitants of the Vale do Jequitinhonha, or perhaps because of it, few studies have assessed the oral conditions of the population of this region, especially with regard to the prevalence of alterations on the oral mucosa. Once these alterations are studied in different populations, subsequent epidemiological studies will then be able to provide an understanding of the prevalence, extent and severity of oral diseases in order to investigate the factors associated with these diseases and assist in the distribution of public health resources. ${ }^{16}$

Therefore, the purpose of this study was to determine the prevalence and associated factors of oral mucosa alterations among 511 patients aged 12 to 78 years attending an oral health service in Vale do Jequitinhonha, Brazil.

\section{Methodology}

The present cross-sectional study was carried out on a sample of 511 patients who were treated in the dental clinics of the Federal University of Vales of Jequitinhonha and Mucuri (UFVJM), located in Diamantina, Minas Gerais, Brazil. Patients of both genders and above age 12 who sought care in the clinics between March and August of 2009 were included in the study.

The research team consisted of five investigators. The research was divided into two stages. In the first stage, 20 patients who were not part of the main study were randomly selected and evaluated for the presence or absence of oral mucosa alterations. The diagnostic results were compared with a gold standard (minimum kappa value $=0.81$, max- $^{-}$ imum kappa value $=0.89$ ), and any differences of opinion were discussed among the researchers and resolved through consensus. In the second stage, photographs of oral mucosa alterations in a color atlas were observed. Images of lesions not observed in the first clinical stage were selected.

Using questionnaires administered through faceto-face interviews, information such as age, gender, race, medical and pharmacological history and alcohol and cigarette use was collected. Participants were then subjected to a clinical examination of the oral mucosa through direct inspection of the oral cavity under artificial light (KAVO, São Paulo, Brazil) and with the use of disposable wooden spatulas (Estilo, São Paulo, Brazil). Examinations were performed according to World Health Organization criteria, ${ }^{17,18}$ and biosafety standards were observed. At the time of examination, all participants were informed of the state of their oral mucosa and were referred to the appropriate departments depending on their treatment needs.

Twenty-six types of oral mucosa alterations were observed. The cases that required additional tests to confirm the diagnosis were referred to the UFVJM stomatology clinic for biopsy and were included in this study only after a definitive diagnosis was obtained.

The collected data were analyzed by the Statistical Package for Social Science Software (SPSS for Windows, version 17.0, SPSS Inc., Chicago, USA). Initially, we performed a descriptive analysis of the absolute and relative frequencies of all of the variables in the study. Next, we used the Chi-squared test to verify any associations that we found between oral mucosa alterations and each of the independent variables. A p-value $\leq 0.05$ was accepted as significant. All independent variables that were significantly associated ( $p$-values $\leq 0.20$ ) with the more frequent oral mucosa alterations were included in our multivariate logistic regression model.

The study received approval from the Ethics Committee of the UFVJM. The patients were informed about the objectives, risks and benefits of the work and signed informed consent forms after agreeing to participate.

\section{Results}

A total of 511 patients with an average age of 33.3 years $(S D=9.5)$ participated in this study. The results of the frequency analysis of the studied variables are presented in Table 1. 
Table 1 - Absolute and relative frequencies of the variables studied.

\begin{tabular}{|c|c|c|}
\hline Variables & Absolute Fre & quency (relative) \\
\hline \multicolumn{3}{|c|}{ Oral Mucosa Alterations } \\
\hline Yes & 434 & $(84.9 \%)$ \\
\hline No & 77 & (15.1\%) \\
\hline \multicolumn{3}{|c|}{ Gender } \\
\hline Female & 367 & $(71.8 \%)$ \\
\hline Male & 144 & $(28.2 \%)$ \\
\hline \multicolumn{3}{|c|}{ Age } \\
\hline $12-19$ years & 90 & $(17.6 \%)$ \\
\hline $20-59$ years & 395 & $(77.3 \%)$ \\
\hline $60-78$ years & 26 & $(5.1 \%)$ \\
\hline \multicolumn{3}{|c|}{ Race } \\
\hline White & 170 & (33.3\%) \\
\hline Phaeoderm & 244 & $(47.7 \%)$ \\
\hline Black & 97 & (19.0\%) \\
\hline \multicolumn{3}{|c|}{ Systemic Diseases } \\
\hline Hypertension & 25 & $(4.9 \%)$ \\
\hline Neurological disorders & 17 & $(3.3 \%)$ \\
\hline Endocrinopathy & 16 & $(3.2 \%)$ \\
\hline \multicolumn{3}{|c|}{ Medications } \\
\hline Analgesics & 64 & $(12.5 \%)$ \\
\hline Antihypertensive & 41 & (8.0\%) \\
\hline Anxiolytic & 30 & $(5.9 \%)$ \\
\hline Anti-inflammatory & 8 & $(1.6 \%)$ \\
\hline \multicolumn{3}{|c|}{ Cigarette Use } \\
\hline Yes & 80 & $(15.7 \%)$ \\
\hline No & 431 & (84.3\%) \\
\hline \multicolumn{3}{|c|}{ Alcohol Use } \\
\hline Yes & 223 & $(43.6 \%)$ \\
\hline No & 288 & $(56.4 \%)$ \\
\hline Total & 511 & (100.0\%) \\
\hline
\end{tabular}

In this study, 833 oral mucosa alterations were found in 434 participants $(84.9 \%$ ), and some individuals had more than one type of alteration (Table 1). A total of twenty-six different mucosal changes were diagnosed, the most common of which were melanotic maculae $(36.0 \%)$, linea alba $(33.9 \%)$, traumatic ulcers $(21.5 \%)$, Fordyce's granules $(20.4 \%)$, coated tongue $(12.5 \%)$ and fissured tongue $(10.0 \%)$ (Table 2).
In this study, the prevalence of these alterations was different between the genders. Fissured tongue, coated tongue and linea alba $(\mathrm{p}<0.05)$ were most prevalent in female subjects $(\mathrm{p}<0.05$; Table 2$)$. Statistically significant associations were observed between the group ranging from 20 to 59 years of age and melanotic maculae $(\mathrm{p}<0.05$; Table 3$)$.

The results of logistic regression analyses on factors most commonly associated with the most prevalent oral mucosa alterations are presented in Table 4.

\section{Discussion}

This study's findings should be interpreted with caution because we found that the prevalence of certain oral mucosa alterations was relatively low. Furthermore, comparison with other epidemiological studies is complicated by different experimental methodologies. However, the wide variety of oral mucosa alterations identified in this study is consistent with the findings of other reports. ${ }^{4-7,70,12,14}$

Of the 511 patients enrolled in this study, $71.8 \%$ $(n=367)$ were female. This overrepresentation of female patients has also been observed in other epidemiological studies of the prevalence of oral mucosa alterations. ${ }^{5,10,13,14}$ It is possible that this observation reflects a greater concern about oral health among women than among men. ${ }^{11,19}$

The prevalence of oral mucosa alterations found in this study was higher $(84.9 \%)$ than in similar studies in Spain ${ }^{7}$ (51.9\%) and Turkey ${ }^{10}(41.7 \%)$. Such variations in the prevalence rates of oral mucosa alterations may be the result of geographical differences, socio-demographic characteristics of the study populations, and a lack of standardized diagnostic criteria and experimental methodologies. ${ }^{4-12}$

Lesions of a traumatic origin are those most commonly reported in different parts of the world. ${ }^{11}$ In this study, traumatic ulcer $(21.5 \%)$, inflammatory fibrous hyperplasia (2.3\%), hyperkeratosis $(0.2 \%)$ and prosthesis-induced mucositis accounted for $58.1 \%$ of the total mucosal alterations, which are quite high compared to the previously-reported values of $7.8 \%$ and $5.6 \%$ reported in two studies of an adult Brazilian population. ${ }^{20,21}$ This might be due to the fact that the participants in our study were 
Table 2 - The distribution of oral mucosa alterations according to gender.

\begin{tabular}{|c|c|c|c|c|c|c|}
\hline \multirow{3}{*}{ Oral mucosa alterations } & \multicolumn{2}{|c|}{ Female } & \multicolumn{2}{|c|}{ Male } & \multicolumn{2}{|c|}{ Total } \\
\hline & \multicolumn{2}{|c|}{$(n=367,71.8 \%)$} & \multicolumn{2}{|c|}{$(n=144,28.2 \%)$} & \multicolumn{2}{|c|}{$(n=511,100 \%)$} \\
\hline & $\mathrm{n}$ & $\%$ & $\mathrm{n}$ & $\%$ & $n$ & $\%$ \\
\hline \multicolumn{7}{|c|}{ Pigmentation } \\
\hline Melanotic maculae & 130 & 70.7 & 54 & 29.3 & 184 & 36.0 \\
\hline \multicolumn{7}{|c|}{ Tongue lesions } \\
\hline Fissured tongue & 30 & 58.8 & 21 & 41.2 & 51 & $10.0^{*}$ \\
\hline Coated tongue & 38 & 59.4 & 26 & 40.6 & 64 & $12.5^{*}$ \\
\hline Varices & 4 & 80.0 & 1 & 20.0 & 5 & 1.0 \\
\hline Hairy tongue & 2 & 100.0 & 0 & 0.0 & 2 & 0.4 \\
\hline Geographic tongue & 7 & 70.0 & 3 & 30.0 & 10 & 2.0 \\
\hline \multicolumn{7}{|c|}{ Infections } \\
\hline Angular cheilitis & 6 & 60.0 & 4 & 40.0 & 10 & 2.0 \\
\hline Exfoliative cheilitis & 3 & 50.0 & 3 & 50.0 & 6 & 1.2 \\
\hline Actinic cheilitis & 1 & 50.0 & 1 & 50.0 & 2 & 0.4 \\
\hline Candidiasis & 11 & 84.6 & 2 & 15.4 & 13 & 2.5 \\
\hline Recurrent herpes & 3 & 60.0 & 2 & 40.0 & 5 & 1.0 \\
\hline Abscess/Fistula & 2 & 100.0 & 0 & 0.0 & 2 & 0.4 \\
\hline \multicolumn{7}{|c|}{ Traumatic mucosa lesions } \\
\hline Linea alba & 136 & 78.6 & 37 & 21.4 & 173 & $33.9^{*}$ \\
\hline Traumatic ulcers & 76 & 69.1 & 34 & 30.9 & 110 & 21.5 \\
\hline Inflammatory fibrous hyperplasia & 1 & 100.0 & 0 & 0.0 & 1 & 0.2 \\
\hline Hyperkeratosis & 1 & 100.0 & 0 & 0.0 & 1 & 0.2 \\
\hline Mucositis by prosthesis & 1 & 100.0 & 0 & 0.0 & 1 & 0.2 \\
\hline Fordyce's granules & 67 & 64.4 & 37 & 35.6 & 104 & 20.4 \\
\hline Leukoedema & 15 & 45.5 & 18 & 54.5 & 33 & $6.5^{*}$ \\
\hline Aphtha & 10 & 71.4 & 4 & 28.6 & 14 & 2.7 \\
\hline Mandibular torus & 11 & 84.6 & 2 & 15.4 & 13 & 2.5 \\
\hline Palatine torus & 3 & 33.3 & 6 & 66.7 & 9 & $1.8^{*}$ \\
\hline Buccal exostosis & 3 & 75.0 & 1 & 25.0 & 4 & 0.8 \\
\hline Amalgam tattoo & 3 & 100.0 & 0 & 0.0 & 3 & 0.6 \\
\hline Sturge Web syndrome & 1 & 100.0 & 0 & 0.0 & 1 & 0.2 \\
\hline Burning mouth syndrome & 1 & 100.0 & 0 & 0.0 & 1 & 0.2 \\
\hline
\end{tabular}

Chi-square test. *Statistically significant, according to gender $(p<0.05)$. seeking dental care for traumatic agents in the oral cavity, such as maladapted partial or complete removable dentures, malocclusion, dental caries or unsatisfactory restorations.

Melanotic maculae were the most prevalent oral mucosa alteration, found in $36.0 \%$ of cases and with a higher frequency in black patients (OR: 7.66). A number of studies also report an association between melanotic maculae and the black race. ${ }^{22-}$ ${ }^{24}$ In this study, the lower prevalence of melanotic maculae among subjects aged 60 to 78 years (OR: $0.20)$ has no definite relationship. A knowledge of 
Table 3 - The distribution of oral mucosa alterations according to age group.

\begin{tabular}{|c|c|c|c|c|c|c|c|}
\hline \multirow{3}{*}{ Oral mucosa alterations } & \multirow{2}{*}{\multicolumn{2}{|c|}{$\begin{array}{c}12-19 \text { years } \\
(n=90,17.6 \%)\end{array}$}} & \multirow{2}{*}{\multicolumn{2}{|c|}{$\begin{array}{c}20-59 \text { years } \\
(n=395,77.3 \%)\end{array}$}} & \multirow{2}{*}{\multicolumn{2}{|c|}{$\begin{array}{c}60-78 \text { years } \\
(n=26,5.1 \%)\end{array}$}} & \multirow{3}{*}{$\begin{array}{c}\text { Total } \\
\mathrm{n}\end{array}$} \\
\hline & & & & & & & \\
\hline & $n$ & $\%$ & $\mathrm{n}$ & $\%$ & $\mathrm{n}$ & $\%$ & \\
\hline \multicolumn{8}{|c|}{ Pigmentation } \\
\hline Melanotic maculae & 38 & 20.7 & 142 & 77.2 & 4 & 2.2 & $184^{*}$ \\
\hline \multicolumn{8}{|c|}{ Tongue lesions } \\
\hline Fissured tongue & 10 & 19.6 & 35 & 68.6 & 6 & 11.8 & 51 \\
\hline Coated tongue & 9 & 14.1 & 51 & 79.7 & 4 & 6.3 & 64 \\
\hline Varices & 0 & 0.0 & 3 & 60.0 & 2 & 40.0 & $5^{*}$ \\
\hline Hairy tongue & 0 & 0.0 & 2 & 100.0 & 0 & 0.0 & 2 \\
\hline Geographic tongue & 4 & 40.0 & 6 & 60.0 & 0 & 0.0 & 10 \\
\hline \multicolumn{8}{|c|}{ Infections } \\
\hline Angular cheilitis & 1 & 10.0 & 7 & 70.0 & 2 & 20.0 & 10 \\
\hline Exfoliative cheilitis & 0 & 0.0 & 6 & 100.0 & 0 & 0.0 & 6 \\
\hline Actinic cheilitis & 0 & 0.0 & 1 & 50.0 & 1 & 50.0 & 2 \\
\hline Candidiasis & 1 & 7.7 & 9 & 69.2 & 3 & 23.1 & 13 \\
\hline Recurrent herpes & 1 & 20.0 & 4 & 80.0 & 0 & 0.0 & 5 \\
\hline Abscess/Fistula & 0 & 0.0 & 2 & 100.0 & 0 & 0.0 & 2 \\
\hline \multicolumn{8}{|c|}{ Traumatic mucosa lesions } \\
\hline Linea alba & 33 & 19.1 & 135 & 78.0 & 5 & 2.9 & 173 \\
\hline Traumatic ulcers & 17 & 15.5 & 86 & 78.2 & 7 & 6.4 & 110 \\
\hline Inflammatory fibrous hyperplasia & 0 & 0.0 & 10 & 83.3 & 2 & 16.7 & 12 \\
\hline Hyperkeratosis & 0 & 0.0 & 1 & 100.0 & 0 & 0.0 & 1 \\
\hline Mucositis by prosthesis & 0 & 0.0 & 1 & 100.0 & 0 & 0.0 & 1 \\
\hline Fordyce's granules & 17 & 16.3 & 78 & 75.0 & 9 & 8.7 & 104 \\
\hline Leukoedema & 4 & 12.1 & 27 & 81.8 & 2 & 6.1 & 33 \\
\hline Aphtha & 1 & 7.1 & 13 & 92.9 & 0 & 0.0 & 14 \\
\hline Mandibular torus & 1 & 7.7 & 10 & 76.9 & 2 & 15.4 & 13 \\
\hline Palatine torus & 0 & 0.0 & 9 & 100.0 & 0 & 0.0 & 9 \\
\hline Buccal exostosis & 1 & 25.0 & 3 & 75.0 & 0 & 0.0 & 4 \\
\hline Amalgam tattoo & 0 & 0.0 & 3 & 100.0 & 0 & 0.0 & 3 \\
\hline Sturge Web syndrome & 0 & 0.0 & 1 & 100.0 & 0 & 0.0 & 1 \\
\hline Burning mouth syndrome & 0 & 0.0 & 0 & 0.0 & 1 & 100.0 & $1^{* *}$ \\
\hline \multicolumn{8}{|c|}{ Total of oral mucosa alterations: 833} \\
\hline
\end{tabular}

Chi-squared test. ${ }^{*}$ Statistically significant, according to age $(\mathrm{P}<0.05) .{ }^{* *}$ Statistically significant, according to age $(P<0.001)$.

this alteration and an ability to properly identify it in patients is important, as melanin pigmentation in the oral mucosa may require a diagnostic biopsy. ${ }^{25,26}$ Moreover, although this condition was not found to be associated with tobacco use in this study, previous studies have reported a possible association be- tween smoking and the development of melanotic maculae. ${ }^{22,24}$

Fordyce's granules are ectopic sebaceous glands that accounted for $20.4 \%$ of the oral mucosa alterations identified in our study. This prevalence is higher than that found in studies conducted in Tur- 
- Oral mucosa alterations in a socioeconomically deprived region: prevalence and associated factors

Table 4 - Logistic regression results for the most prevalent oral mucosa alterations.

\begin{tabular}{|c|c|c|}
\hline Alterations most prevalent & Odds Ratio (OR) (Cl 95\%) & $p$ \\
\hline \multicolumn{3}{|c|}{ Melanotic Maculae } \\
\hline Gender (Male:0; Female: 1) & $0.97(0.64-1.48)$ & 0.901 \\
\hline \multicolumn{3}{|l|}{ Age } \\
\hline $12-19$ years & 1.00 & \\
\hline $20-59$ years & $0.71(0.43-1.11)$ & 0.186 \\
\hline $60-78$ years & $0.20(0.06-0.66)$ & $0.008^{*}$ \\
\hline \multicolumn{3}{|l|}{ Race } \\
\hline White & 1.00 & \\
\hline Feoderm & $6.12(3.60-10.40)$ & $0.000^{*}$ \\
\hline Black & $7.51(4.00-14.09)$ & $0.000^{*}$ \\
\hline \multicolumn{3}{|c|}{ Linea alba } \\
\hline Gender (Male:0; Female:1) & $1.90(1.21-2.96)$ & $0.005^{*}$ \\
\hline \multicolumn{3}{|l|}{ Age } \\
\hline $12-19$ years & 1.00 & \\
\hline $20-59$ years & $0.85(0.51-1.41)$ & 0.543 \\
\hline $60-78$ years & $0.35(0.11-1.05)$ & 0.062 \\
\hline \multicolumn{3}{|c|}{ Traumatic Ulcers } \\
\hline Gender (Male:0; Female:1) & $0.88(0.55-1.42)$ & 0.616 \\
\hline \multicolumn{3}{|l|}{ Age } \\
\hline $12-19$ years & 1.00 & \\
\hline $20-59$ years & $1.17(0.64-2.12)$ & 0.597 \\
\hline $60-78$ years & $1.49(0.52-4.22)$ & 0.450 \\
\hline \multicolumn{3}{|c|}{ Fordyce's Granules } \\
\hline Gender (Male:0; Female: 1) & $0.66(0.41-1.06)$ & 0.093 \\
\hline \multicolumn{3}{|l|}{ Age } \\
\hline $12-19$ years & 1.00 & \\
\hline $20-59$ years & $1.03(0.56-1.87)$ & 0.919 \\
\hline $60-78$ years & $2.19(0.81-5.94)$ & 0.122 \\
\hline \multicolumn{3}{|c|}{ Coated Tongue } \\
\hline Gender (Male:0; Female: 1) & $1.69(0.96-2.97)$ & 0.066 \\
\hline \multicolumn{3}{|l|}{ Age } \\
\hline $12-19$ years & 1.00 & \\
\hline $20-59$ years & $0.74(0.20-2.70)$ & 0.649 \\
\hline $60-78$ years & $0.87(0.28-2.73)$ & 0.822 \\
\hline \multicolumn{3}{|c|}{ Fissured Tongue } \\
\hline Gender (Male:0; Female:1) & $2.11(1.12-3.96)$ & $0.020^{*}$ \\
\hline \multicolumn{3}{|l|}{ Age } \\
\hline 12-19 years & 1.00 & \\
\hline $20-59$ years & $1.00(0.29-3.44)$ & 0.993 \\
\hline $60-78$ years & $0.60(0.21-1.72)$ & 0.345 \\
\hline
\end{tabular}

*Statistically significant $(P<0.05)$. ${ }^{*}$ Statistically significant $(P<0.001)$. 
key $^{10}(1.3 \%)$ and $\operatorname{India}^{27}(6.5 \%)$, but lower than that reported in studies carried out in Thailand $(57.7 \%)$, Mexico $^{22}$ (55.0\%) and Malaysia ${ }^{23}$ (61.8\%). This presence of Fordyce's granules was not significantly associated with any independent variables evaluated in the present investigation. However, a number of previous studies have reported that the prevalence of Fordyce's granules increases with age ${ }^{6,22}$ and is higher in the male gender. ${ }^{21}$

Epidemiological studies conducted in different parts of the world have found tongue lesions to be among the most common alterations of the oral mucosa. ${ }^{4,10,22,23}$ Our study corroborates these findings, as coated tongue $(12.5 \%)$ and fissured tongue $(10.0 \%)$ were among the seven most prevalent alterations that we identified. Coated tongue may be related to a poor oral health status, ${ }^{4,7,28}$ which has in turn been associated with low socioeconomic status. ${ }^{28}$ This association between poor overall oral health and low socioeconomic status may explain the high prevalence of this condition in the population studied. However, a number of studies have reported a statistically significant association between coated tongue and tobacco smoking, ${ }^{4}$ which we did not observe in this study.

Linea alba and fissured tongue were significantly associated with the female gender $(\mathrm{p}<0.05)$, occurring approximately twice as frequently in females than in males. This finding was previously reported in a study conducted in Turkey. ${ }^{10}$ Some studies report a higher incidence of fissured tongue among men $^{5}$ and elderly patients. ${ }^{10}$ Others report a statistically significant association between fissured tongue

\section{References}

1. Canaan TJ, Meehan SC. Variations of structure and appearance of the oral mucosa. Dent Clin North Am. 2005 Jan;49(1):1-14, vii.

2. Rioboo-Crespo M del R, Planells-del Pozo P, Rioboo-García R. Epidemiology of the most common oral mucosal diseases in children. Med Oral Patol Oral Cir Bucal. 2005 NovDec;10(5):376-87.

3. Crivelli MR, Águas S, Quarrancino C, Bazerque P. Influence of the socioeconomic status on oral mucosa lesion prevalence in schoolchildren. Community Dent Oral Epidemiol. 1988 Feb;16(1):58-60. and a history of allergy. ${ }^{9}$ However, we did not find these associations in the present study.

The fact that we did not observe a statistically significant association between the main oral mucosa alterations and a patient's status with respect to systemic disease, alcohol use and tobacco use may be due to the hereditary characteristics of the oral mucosa alterations reported.

The results of this study provide a basis for future studies involving regions with known socioeconomic deprivation, such as the Vale do Jequitinhonha, and may contribute toward public policies directed at oral disease prevention and control programs in this region.

\section{Conclusions}

The alterations most commonly identified in this study were melanotic maculae, linea alba, traumatic ulcers, Fordyce's granules, coated tongue and fissured tongue. Furthermore, we found that gender, age and race were all factors that were significantly associated with the presence of oral mucosa alterations.

The high prevalence of melanotic maculae and Fordyce's granules indicates that these alterations should be considered normal characteristics of the population of the Vale do Jequitinhonha. On the other hand, the high prevalence of coated tongue may be related to the socioeconomic deprivation in the region and traumatic ulcers may be associated with the traumatic agents that caused patients to seek dental care.

4. Campisi G, Margiotta V. Oral mucosal lesions and risk habits among men in a Italian study population. J Oral Pathol Med. 2001Jan;30(1):22-8.

5. Kovac-Kavcic M, Skaleric U. The prevalence of oral mucosal lesions in a population in Ljubljana, Slovenia. J Oral Pathol Med. 2000 Aug;29(7):331-5.

6. Reichart PA. Oral mucosal lesions in a representative crosssectional study of aging Germans. Community Dent Oral Epidemiol. 2000 Oct;28(5):390-8. 
7. Martínez Díaz-Canel AI, García-Pola Vallejo MJ. Epidemiological study of oral mucosa pathology in patients of the Oviedo School of Stomatology. Med Oral. 2002 Jan-Feb;7(1):4-9.

8. Espinoza I, Rojas R, Aranda W, Gamonal J. Prevalence of oral mucosal lesions in elderly people in Santiago, Chile. J Oral Pathol Med. 2003 Nov;32(10):571-5.

9. Bessa CF, Santos PJ, Aguiar MC, do Carmo MA. Prevalence of oral mucosal alterations in children from 0 to 12 years old. J Oral Pathol Med. 2004 Jan;33(1):17-22.

10. Mumcu G, Cimilli H, Sur H, Hayran O, Atalay T. Prevalence and distribution of oral lesions: a cross-sectional study in Turkey. Oral Dis. 2005 Mar;11(2):81-7.

11. Castellanos JL, Díaz-Guzmán L. Lesions of the oral mucosa: an epidemiological study of 23785 Mexican patients. Oral Surg Oral Med Oral Pathol Oral Radiol Endod. 2008 Jan;105(1):79-85.

12. Mujica V, Riveira H, Carrero M. Prevalence of oral soft tissue lesions in an elderly venezuelan population. Med Oral Patol Oral Cir Bucal. 2008 May;13(5): E270-4.

13. Vasconcelos BC, Novaes M, Sandrini FA, Maranhão Filho AW, Coimbra LS. Prevalence of oral mucosa lesions in diabetic patients: a preliminary study. Braz J Otorrinolaringol. 2008 May-Jun;74(3):423-8.

14. Ferreira RC, Magalhães CS, Moreira AN. Oral mucosal alterations among the institutionalized elderly in Brazil. Braz Oral Res. 2010 Jul-Sep;24(3):296-302.

15. Ferreira VA, Silva AE, Rodrigues CA, Nunes NL, Vigato TC, Magalhães R. [Inequality, poverty and obesity]. Cien Saude Colet. 2010 Jun;15 Suppl 1:1423-32. Portuguese.

16. Pack AR. Dental services and needs in developing countries. Int Dent J. 1998 Jun;48(3 Suppl 1):239-47.

17. Kramer IR, Pindborg JJ, Bezroukov V, Infirri JS. Guide to epidemiology and diagnosis of oral mucosal diseases and conditions. World Health Organization. Community Dent Oral Epidemiol. 1980 Feb;8(1):1-26.

18. World Health Organization. Application of the international classification of diseases to dentistry and stomatology. Geneva: Word Health Organization; 1995. 246 p.
19. Covington P. Women's oral health issues: an exploration of the literature. Probe. 1996 Sep-Oct;30(5):173-7.

20. dos Santos PJ, Bessa CF, de Aguiar MC, do Carmo MA. Crosssectional study of oral mucosal conditions among a central Amazonian indian community, Brazil. J Oral Pathol Med. 2004 Jan;33(1):7-12.

21. Henrique PR, Bazaga Júnior M, Araújo VC, Junqueira JLC, Furuse C. Prevalência de alterações da mucosa bucal em indivíduos adultos da população de Uberaba, Minas Gerais. RGO. 2009 Jul;57(3):261-7.

22. Cornejo AD, Huerta ERL, Bravo SP, Barrios BA, Riviera DQ, Yañez AB, et al. Distribucuión de condiciones y lesiones de la mucosa bucal en pacientes adultos mexicanos. Rev Cubana Estomatol. 2007 Mar;44(1):181-9.

23. Axell T, Zain RB, Siwamogstham P, Tantiniran D, Thampipit J. Prevalence of oral soft tissue lesions in out-patients at two Malaysian and Thai dental schools. Community Dent Oral Epidemiol. 1990 Apr;18(2):95-9.

24. Hedin CA, Axell T. Oral melanin pigmentation in 467 Thai and Malaysian people with special emphasis on smoker's melanosis. J Oral Pathol Med. 1991 Jan;20(1):8-12.

25. Ciçek Y, Ertaş U. The normal and pathological pigmentation of oral mucous membrane: a review. J Contemp Dent Pract. 2003 Aug;4(3):76-86.

26. Meleti M, Vescovi P, Mooi WJ, van der Waal I. Pigmented lesions of the oral mucosa and perioral tissues: a flow-chart for the diagnosis and some recommendations for the management. Oral Surg Oral Med Oral Pathol Oral Radiol Endod. 2008 May;105(5):606-16.

27. Mathew AL, Pai KM, Sholapurkaar AA, Vengal M. The prevalence of oral mucosa lesions in patients visiting a dental school in Southern India. Indian J Dent Res. 2008 AprJun;19(2):99-103.

28. Nevalainen MJ, Narhi TO, Ainamo A. Oral mucosal lesions and oral hygiene habits in the home-living elderly. J Oral Rehabil 1997 May;24(5):332-7. 